\title{
Measurement the difference gender perspective of social dimension satisfaction of quality of urban life in central texture of coastal city of Bandar Abbas
}

\author{
Roya Honarkhah ${ }^{1}$,Sana Zarei and ${ }^{2}$ Mahdi Ghaedi ${ }^{3}$ \\ ${ }^{1,2}$ Young researchers and elite club,Bandar Abbas branch,Islamic azad university,Bandar Abbas,Iran \\ ${ }^{3}$ Department of Architecture, Bandar Abbas Branch, Islamic Azad University, Bandar Abbas , Iran
}

\section{Article history:}

Received date: 11 October, 2019

Review date: 15 December 2019

Accepted date:25 January 2020

\section{Keywords:}

Quality of urban life, satisfaction, social dimension, coastal city of Bandar Abbas.

\begin{abstract}
Quality of life is a complex and multi-dimensional word of visualization from moment to moment of life experiences That is based on objective indicators as well as subjective indicators. In this research quality of urban life according to the definition by Cutter: Life satisfaction is meaningless. It is tried, to measure the amount of difference between men and women perceptions from satisfaction of quality of life in subjective indicators of social dimension in central texture of Bandar Abbas. Accordingly social dimension of quality of life indicators is collected by libraries and they have been developed and localization After consultations with professors and experts, In this research 158 people have participated that have responded to a questionnaire Likert spectrum. Data obtained from questionnaires have been analysis by using SPSS software and then were assessed by using t-test and nonparametric Kolmogorov-Smirinov, differences of opinion between men and women between the social indicators of quality of life. The results show that Quality of life in social dimension is located relatively moderate to high and In the number of indicators are significant differences in distribution of responsibility between women and men.
\end{abstract}

Please cite this article as: Honarkhah R., Zarei S., Ghaedi M. 2019. Measurement the difference gender perspective of social dimension satisfaction of quality of urban life in central texture of coastal city of Bandar Abbas. KURMANJ; The Journal of Culture, Humanities and Social Science, 2(1), 1-10

\section{Introduction:}

The concept of quality of life is pay attention to social, cultural, economic, environmental and psychological dimensions in two aspects of objective and subjective In the process of urban planning And main essence urban life quality is supply and satisfy the needs of material and spiritual human By simultaneously . Cutter in 1985, defines the quality of life: Quality of life is determined based on the amount individual happiness and life satisfaction And environment, including the needs, wishes and other tangible and intangible factors that determine the overall welfare. Therefore, one of the criteria that quality of life can be assessed with it , amount of personal satisfaction of subjective quality of life indicators and variables.

Quality of life the important issues that initially widespread deployment of technology and industrialization process were of interest to scientists in Western countries. Step with increases in population, urbanization and concentration of industry were grown funds, facilities and urban services . and the big cities have become to metropolitan cities And create complicated and difficult problems .Cities encountered with an increase in social anomalies, fading sense of identity And a sense of social belonging,, housing shortages, and expanding social ecology and environmental problems and in total reduced quality of life (sarrafi ,2003,37).

Coastal cities also are known due to ecological valuable resources, biological diversity and the presence of nature is one of the most sensitive and the most valuable areas in the world . A collection of sea and coast as the main elements coastal towns and evocative space and historical of cities can play a role in the formation the city So that it is usually formation of the core and the city's historic center at the edge. So attention to the ability of the coast be different them from another regular zone that should be treated with each land. Unfortunately, a number of factors, such as lack of appropriate planning and design with a coastal city of in 
accordance with its climate and ecology and on the one hand lack of attention to human needs in the planning and the flood of migration to the the cities and increasing population on the other hand, they are Caused creation of problems including the lack of appropriate coastal areas, lack of appropriate and attractive urban space, environmental pollution, development activities incompatible with the environment and lack of coordination between the activities, security and so on, that makes residents of these cities are not satisfied with the quality of your life.

Bandar Abbas city as the largest seaport of Iran ,it Is no exception. Todays Bandar Abbas due to the sevral endogenous and exogenous factors, this has problems including : its has place Most immigrant population And the majority Just look as the city to monetize And the problems is more pronounced

in areas including the main and old areas of the city.One of the areas ,it is the central texture of Bandar Abbas as a primary and main core of this city and since this texture is a linking the central of city to the new texture or downtown and more activities has been established in this context, that it emphasis is on the importance of this texture. This texture as will impact Activities and actions of the surrounding environment, they also have an impact. So having a appropriate quality of urban life can be to play embossed in the field of economic, social and cultural city. Therefore, measure quality of life and followed by the identification of differences of opinion between men and women, Can be used as an important approach In planning a great help to improve the quality of urban life.

Overall the main objective of this research is to evaluate differences of opinion the satisfaction between men and women from the multiple social indicators of quality of life such as security ,residents perceived of amount of sens of belonging, amount of satisfaction of coastal sport - recreational spaces, satisfaction of green space and leisure services. In this research considering that is measured amount of satisfaction residents, Quality of life is considered from the dimension of subjective. And in this regard designed the research questions are as follows:

- what level is the Subjective quality of life In central texture of Bandar Abbas?

- Is there a significant difference the distribution of female and male respondents of satisfaction of the social dimension of quality of life in texture of Bandar Abbas?

\section{The definition of quality of urban life:}

Many studies have been done on the concept of quality of life throughout the world(Delfim,2006:411).The quality of life has content and overall concept and researches with different approaches and theory have addressed to its various aspects.(Uzzell,2006;Vankamp and Others,2003). Elgin and his colleagues are saying about the quality of life in urban environments in 1974: a city While provider a better quality of life That will help to appropriate conditions for a selected population and their mental attitude about the situation. Liu says from an economic perspective in 1976 : The quality of life is for a new name for an old term meaning as "general welfare" and "social welfare" . In 1976, Leo states from an economic point of view that life quality is a new name for an old term, i.e. "public welfare" and "social welfare". Moreover, in 1983 he describes life quality as "a new title for the old concept of people's physical and mental welfare in their living environments." In 1980, Sezalli asserts that "life quality is associated with the degree of satisfaction with life." The individual's existential state in welfare and satisfaction with life is determined, on the one hand, by the external facts or objective factors of life, and on the other, by the individual's own internal perception or assessment of life's factors and facts. In 1985, Cutter describes life quality by saying "life quality is determined with regards to the degree of individual happiness and satisfaction with life, and environment includes needs, desires, and other tangible and intangible factors that determine the general welfare. In 2007, Costanza et al. define life quality as the degree of human needs provision associated with people's and groups' perceptions of mental welfare (Costanza, 2007). In 2008, Das asserts that "life quality refers to people's welfare in the environment they live in" and defines life quality as the welfare or lack of welfare of people and the environment they live in (Das, 2008). Thus, life quality depends on environment quality.

Definition of urban life quality is different in various countries or even various areas of a country, but it is centered around the simultaneously subjective and objective provision of essential physical and spiritual needs (Kokabi, 76: 1386). Generally, life quality is evaluated using two criteria:

1. The first method uses objective criteria for evaluating life quality. Objective criteria are evaluable social and economic indicators reflecting the degree of human needs provision, and are analyzed using official 
reports and statistics. These criteria demonstrate the apparent and tangible conditions of life. In this method, indicators such as gross domestic product, main progress indicator, social health indicator, and human development indicator are used to carry out national and international comparisons.

2. In the second method, there are subjective criteria which evaluate the level of individuals' and groups' satisfaction -also called subjective welfare (Costanza, 2007, 268). These criteria are based on individuals' reports of their perceptions of different aspects of life. These criteria that supplement social, economic, and environmental variables, demonstrate individuals' perceptions and evaluations of their lives' objective state. Subjective criteria are obtained through surveying people's perceptions, evaluations and satisfaction regarding urban life, whereas objective criteria are associated with observable facts which are usually obtained through secondary data (Khadem Al-Hosseini et al., 1389, p. 46). Paying attention to the concept of the subjective aspect is one of the ideas used in life quality researches. This approach, known as the American approach to life quality, stands in opposition to the Scandinavian one. In most of the researches carried out on life quality in America, the researchers have emphasized the individuals' subjective experiences of their lives rather than the subjective indicators. The social psychologist W. I. Thomas could be cited as one of the most influential figures on this approach. In this approach, satisfaction and happiness are considered the main indicators (Azimi, 1389, p. 55). Life quality scholars argue that subjective indicators are more powerful with regards to providing explanations, and the indicators that objectively evaluate the conditions of life can only explain 15 percent of the individual's life quality (Qafari et al., 4, 2009).

\section{The concept of satisfaction;}

The satisfaction concept is point to the vast majorities of inclinations and subliminal needs of the human. Great numbers of people are prone to the things that they will never achieve them and to economical reason they obliged to choose the place, they have loss propensity toward them (Giford,1999,355_360). As we could choose the thing that we aspire, we will satisfy, the primitive study based on our content are pursued according to our single- dimensions view. Some scholars have described the contents based on the conceptions. Thus, a person (male / female) to assess the current conditions of his residence with regard to a collection of needs and aspirations. Overall concept of satisfaction defined in research of field of architecture and housing as criteria that satisfies needs of residents ,Perhaps be different with some other definitions, such as emotional or normative criteria (Lovejoy et al,2010). Needs and aspirations of the feeling by a person is a collection of both individual characteristics (such as social class, life stage, etc.) and cultural factors affecting the person. In recent decades, satisfaction have been proposed in research that related to assess the quality of life in residential areas . In study was conducted by Lansing and Maranz in 1969, satisfaction is the one of the key criteria to assess the quality of the environment And consequently the quality of life And thus did defined the quality of the environment: A high quality environment, the feeling of well-being and satisfaction to its population will pass through the features that may be physical, social or symbolic (Lysyng and Maranz, 196195-199).

\section{subjective State Welfare:}

It's one of our primary positive psychological areas which has links toward our final goal of psychology and could be useful to helping the people. The subjective coexistence is the subcategory of the behavioral science through which the people judgment could done by their ways of life and this field have developed in recent years since there is thousands of studies have done to people contents and their happiness.

This study is complimentary to psychology goal in order to understanding the psychological patience in recent studies, the subjective coexistence the goal is study and understand things that cause people have good feeling towards their values and standards and again its final target is developing of life quality of human by study the process of mind of people. It is the way that persons could define the great life and it point to the happiness. Those who have these feelings have the feeling of happiness and they feel less sadness it has two separate criteria:

The first component is the emotional component that can be divided into positive and negative emotions, the second component is the cognitive component. Commonly refers to life satisfaction. (1993,Pavot \& Diener).

\section{research method:}

The intended purpose of methodology is to provide targeted expression of the principles and framework that will guide the research done. (Mahdizadeh, J., 1381, p. 15). Obviously Research Methodology Depending on 
the type, purpose and object of study can be different. In this research, qualitative research method with a descriptive study-survey is being used. We used qualitative research if only to examine various aspects of a phenomenon (Bazargan, 1394, 30), As well as the documentary method for achieving root of the issue of such the main variables, theoretical models and... has been used. A sample of 158 people were selected based on Cochran formula and the participants have responded to a questionnaire with Likerth range. In order to analyze and verify the authenticity of the questionnaire also uses reliability analysis, Cronbach's alpha coefficient was calculated for all the questions, Cronbach's alpha reliability coefficient is approximately 83/0. Sampling is done randomly. In the next phase the data collected from respondents were entered into SPSS software and based on Kolmogorov-Smirnov test and nonparametric test is been analyzed.

\section{The case study:}

\section{Bandar Abbas City}

Bandar Abbas in Hormozgan province, which is adjacent to the Persian Gulf. Despite the historical background and economic preeminence as one of the most important ports in southern Iran, a small share of the total population in 1382 (about 2\%) is accounted for. It covers an area of 27316 square kilometers. The town is limited from the north to the city Haji Abad and from the East to the towns Minab and Rudan from the west to the town Bandar Lengeh and from the south to the Persian Gulf and Qeshm Island. The people of the city are mainly Muslim Shia and Sunni sects. Now Bandar Abbas population of about 600,000 people. The central role of Bandar Abbas, relying on the services, particularly business services, offices, entertainment and especially transport services and tourism. The role of the nature or character of the port city of Bandar Abbas and its geographic location and placement in the mouth of the Persian Gulf has always been important.

\section{Recognition of Bandar Abbas coastal boulevard:}

Develop and become a major port city of Bandar Abbas, has caused that to be have significant variations in different parts of city in the various aspects Social-Economic-Physical, But an important part of the development processes will be necessarily notice the center of Bandar Abbas.

Today an old center of Bandar Abbas is the place which is called coastal boulevard.

Boulvard it is the heart of Bandar Abbas from inception and constantly playing an important role that mostly were commercial. The coast boulvard of Bandar Abbas is the core of the city and is center of various activities, the number of activities and communications from the sea or air is so it would know as an environment which is so important.

The Boulvard issues and coast side problems become tangled day by day and by day. The bulvard of Bandar Abbas due to the activities, linkage of land and sea that attached like chain make some cases.

-difficulties Commuting of mounted and dismounted on the Boulevard And associated streets and connected to its, Severe shortage of parking on the boulevard .

-Crowded of population.

-Lack of recreation and leisure activities And a very low capacity for public spaces

-Unbeautiy of landscape in urban spaces And confusion in the public image and physical in Boulevard

-Lack of identity in Bandar Abbas regarding with being heedless to architectural values and totally the coast side visage on Bulvard. As Bandar Abbas as a biggest harbor of our country or the gates for come and go or even one of the communicative part to other nations, has no visage and compare to other harbors of our neighbor is the Gorgan induction for our country.

\section{Position seaside boulevard:}

Study site of this research, the Saheli Boulevard of Bandar, Abbas which is the core and heart of the city. This boulevard is limited from the West to the fishermen market (neighborhood posht shahr) and from the East to Gore Creek -Svzan (hotel Hormuz). This part of what is now known as the Saheli Boulevard, since the beginning until recently, were included all banks in Bandar Abbas.

History of the saheli boulevard Bandar Abbas does not exceed 40 years. This boulevard is a wide street with a length of $5.2 \mathrm{~km}$, which is drawn in the vicinity of the sea and the coast of the sea separated by a wall. Saheli Boulevard (Taleghani) is the central region or center of Bandar Abbas. Market, shopping centers, marinas, shops and fish market, mosques and other major buildings that were built in. Existing wall in Blvd 
was built in 1351. Before construction of the quay and the completion of the boulevard, city organization of the sector and the market was limited to the immediate area docks and customs and market; And urban neighborhoods were connected directly and through the narrow alleys of the old neighborhood Lariha, between the city and Ozzieha and by small local pier (made of stone) to the sea. Homes and neighborhoods made directly to scattered near the edge of the sea and in the regional market and customs, building density is higher.

\section{Research Analysis:}

In this study, given that mere attention to the social dimension so the rest of the research process have been removed. And social assessment has been questioned which is composed of four measures and eighteen submeasures. Four measures in this study are: green space and leisure, sports areas - coastal recreation, safety and sense of attachment, then each is examined separately.Table number (1)

\section{Table 1- index and sub-indices of measuring the quality of life in social aspect}

\begin{tabular}{|c|c|c|c|}
\hline & & Residents understanding of the sense of attachment & Sense of attachment \\
\hline & & & Identity \\
\hline & & & Presence in space \\
\hline & & The satisfaction of safety & Undefended spaces and causing offense \\
\hline & & & The absence of vagrants and criminals \\
\hline & & & Safety of the coastal environment \\
\hline & & & The traffic safety \\
\hline & & & The safety of space at night \\
\hline 1 & Social & & Police presence \\
\hline & & & Lighting of beach at night \\
\hline & & & Lighting passages at night \\
\hline & & Satisfaction with green spaces and leisure activities & Green spaces and spending leisure time \\
\hline & & & Quality of green spaces and spending leisure time \\
\hline & & & Abundance of green spaces and spending leisure time \\
\hline & & & Access to green spaces and spending leisure time \\
\hline & & The satisfaction of the cultural-recreational of saheli & Sports Coastal recreational spaces \\
\hline & & & A variety of water sports \\
\hline & & & Access to the beach \\
\hline
\end{tabular}

As the table (2) is specified in the index that smaller amounts equal to 3 is much more than larger amounts of 3 ; and the difference was significantly mainly in the one-thousandth $(p<0.001)$ most people believe that:

1. The range of this study is less part of their identity,

2. The range of this study have a little sense of belonging in them.

3. They have been not present in this place willingly.

4. They believe that defenseless spaces and causing offense in that range can be seen in abundance.

5. Police deployed in the range is less and less useful services.

6. Traveling in this range is associated with stress.

7. Light and lighting at night is not satisfactory in that range.

8. The beach is not safe enough.

9. At night, coast lighting is not enough.

10. In other words, most people believe that green spaces for leisure low or very low. 
11. The abundance of green spaces and parks and spending leisure time space in this range is not in accordance with their needs.

12. Green space and parks (in terms of W.C services, children's playground, children's play equipment and resting places) in this area is not equipped enough.

13. Access to green spaces and spending leisure time spaces (parks and gardens, etc.) is not easily possible.

14. You cannot easily do variety of water sports on the beach (swimming, diving, fishing, beach soccer, etc.).

15. Access to the beach is not easily possible in this range.

Also, in the absence of stray offenders and criminals index, smaller amounts equal 3 with values Larger than 3 is no significant difference, the difference statistically acceptable level $(b<0.87)$ is not meaningful. In other words, the proportion of people who believe that one can see vagrants and criminals is 49 to 51 percent, and cannot easily be seen. Also the safety level indicator in space at night is smaller equal amount 3 less than the quantities greater than 3; And this difference in statistically level is not significant acceptable $(\mathrm{p}<0.26)$. In other words, most people cannot say with high confidence that at night there are many risks for them in this area. In the indicator beach sport-recreational spaces amounts smaller equal 3 is less than amounts larger of 3 , And this difference in the one-thousandth $(\mathrm{p}<0.38)$ is not significant. In other words one cannot say with certainty reasonable that People believe coastal recreational beaches and the perfect places for swimming and water activities for women is low.

Also Among the questions relating to the social aspects, the highest average of the question is, "What time of the night is dangerous for you." which score is 3.535. And the lowest average related to the question, "Can you do all kinds of water sports on beach on desires" which has dedicated his score to 1.563.

Table 2- Calculated parameters related to the following indicators

\begin{tabular}{|c|c|c|c|c|c|c|c|c|}
\hline \multirow{7}{*}{\multicolumn{2}{|c|}{$\begin{array}{l}\text { Residents understanding of } \\
\text { sense of attachment }\end{array}$}} & \multicolumn{2}{|l|}{ Sub-Measure } & \multicolumn{2}{|l|}{$\begin{array}{l}\mathrm{Nu} \\
\mathrm{mb}\end{array}$} & \multirow{3}{*}{$\begin{array}{l}\begin{array}{l}\text { Measures } \\
\text { Comparison }\end{array} \\
0.50\end{array}$} & \multirow{3}{*}{$\begin{array}{l}\text { The significance } \\
\text { level of alpha }\end{array}$} & \multirow{3}{*}{$\begin{array}{l}\begin{array}{l}\text { Ave } \\
\text { rage }\end{array} \\
\begin{array}{l}2.43 \\
3\end{array}\end{array}$} \\
\hline & & Sense of attachment & $\begin{array}{l}\text { Smaller } \\
\text { equal } 3\end{array}$ & 119 & $\begin{array}{l}0.7 \\
6\end{array}$ & & & \\
\hline & & & $\begin{array}{l}\text { Larger } \\
\text { than } 3\end{array}$ & 38 & $\begin{array}{l}0.2 \\
4\end{array}$ & & & \\
\hline & & \multirow[t]{2}{*}{ Identity } & $\begin{array}{l}\text { Smaller } \\
\text { equal } 3\end{array}$ & 122 & $\begin{array}{l}0.7 \\
8\end{array}$ & 0.50 & 0.001 & $\begin{array}{l}2.46 \\
5\end{array}$ \\
\hline & & & $\begin{array}{l}\text { Larger } \\
\text { than } 3\end{array}$ & 35 & $\begin{array}{l}0.2 \\
2\end{array}$ & & & \\
\hline & & \multirow[t]{2}{*}{ Presence in space } & $\begin{array}{l}\text { Smaller } \\
\text { equal } 3\end{array}$ & 109 & $\begin{array}{l}0.7 \\
0\end{array}$ & 0.50 & 0.001 & $\begin{array}{l}2.85 \\
9\end{array}$ \\
\hline & & & $\begin{array}{l}\text { Larger } \\
\text { than } 3\end{array}$ & 47 & $\begin{array}{l}0.3 \\
0\end{array}$ & & & \\
\hline & \multirow[t]{8}{*}{ The satisfaction of safety } & \multirow[t]{2}{*}{$\begin{array}{l}\text { Undefended spaces and } \\
\text { causing offense }\end{array}$} & $\begin{array}{l}\text { Smaller } \\
\text { equal } 3\end{array}$ & 92 & $\begin{array}{l}0.5 \\
9\end{array}$ & 0.50 & 0.04 & $\begin{array}{l}3.22 \\
3\end{array}$ \\
\hline & & & $\begin{array}{l}\text { Larger } \\
\text { than } 3\end{array}$ & 65 & $\begin{array}{l}0.4 \\
1\end{array}$ & & & \\
\hline & & \multirow[t]{2}{*}{$\begin{array}{l}\text { The absence of vagrants and } \\
\text { criminals }\end{array}$} & $\begin{array}{l}\text { Smaller } \\
\text { equal } 3\end{array}$ & 80 & $\begin{array}{l}0.5 \\
1\end{array}$ & 0.50 & 0.87 & $\begin{array}{l}3.42 \\
0\end{array}$ \\
\hline & & & $\begin{array}{l}\text { Larger } \\
\text { than } 3\end{array}$ & 77 & $\begin{array}{l}0.4 \\
9\end{array}$ & & & \\
\hline & & \multirow[t]{2}{*}{$\begin{array}{l}\text { Safety of the coastal } \\
\text { environment }\end{array}$} & $\begin{array}{l}\text { Smaller } \\
\text { equal } 3\end{array}$ & 148 & $\begin{array}{l}0.9 \\
4\end{array}$ & 0.50 & 0.001 & $\begin{array}{l}2.26 \\
1\end{array}$ \\
\hline & & & $\begin{array}{l}\text { Larger } \\
\text { than } 3\end{array}$ & 9 & $\begin{array}{l}0.0 \\
6\end{array}$ & & & \\
\hline & & \multirow[t]{2}{*}{ The traffic safety } & $\begin{array}{l}\text { Smaller } \\
\text { equal } 3\end{array}$ & 133 & $\begin{array}{l}0.8 \\
5\end{array}$ & 0.50 & 0.001 & $\begin{array}{l}2.51 \\
0\end{array}$ \\
\hline & & & $\begin{array}{l}\text { Larger } \\
\text { than } 3\end{array}$ & 24 & $\begin{array}{l}0.1 \\
5\end{array}$ & & & \\
\hline
\end{tabular}




\begin{tabular}{|c|c|c|c|c|c|c|c|}
\hline & \multirow[t]{2}{*}{ The safety of space at night } & $\begin{array}{l}\text { Smaller } \\
\text { equal } 3\end{array}$ & 71 & $\begin{array}{l}0.4 \\
5\end{array}$ & \multirow[t]{2}{*}{0.50} & \multirow[t]{2}{*}{0.26} & \multirow[t]{2}{*}{$\begin{array}{l}3.53 \\
5\end{array}$} \\
\hline & & $\begin{array}{l}\text { Larger } \\
\text { than } 3\end{array}$ & 86 & $\begin{array}{l}0.5 \\
5\end{array}$ & & & \\
\hline & \multirow[t]{2}{*}{ Police presence } & $\begin{array}{l}\text { Smaller } \\
\text { equal } 3\end{array}$ & 137 & $\begin{array}{l}0.8 \\
7\end{array}$ & 0.50 & 0.001 & $\begin{array}{l}2.44 \\
6\end{array}$ \\
\hline & & $\begin{array}{l}\text { Larger } \\
\text { than } 3\end{array}$ & 20 & $\begin{array}{l}0.1 \\
3\end{array}$ & & & \\
\hline & \multirow[t]{2}{*}{ Lighting of beach at night } & $\begin{array}{l}\text { Smaller } \\
\text { equal } 3\end{array}$ & 142 & $\begin{array}{l}0.9 \\
0\end{array}$ & 0.50 & 0.001 & $\begin{array}{l}2.06 \\
4\end{array}$ \\
\hline & & $\begin{array}{l}\text { Larger } \\
\text { than } 3\end{array}$ & 15 & $\begin{array}{l}0.1 \\
0\end{array}$ & & & \\
\hline & \multirow[t]{2}{*}{ Lighting passages at night } & $\begin{array}{l}\text { Smaller } \\
\text { equal } 3\end{array}$ & 136 & $\begin{array}{l}0.8 \\
7\end{array}$ & 0.50 & 0.001 & $\begin{array}{l}2.57 \\
3\end{array}$ \\
\hline & & $\begin{array}{l}\text { Larger } \\
\text { than } 3\end{array}$ & 21 & $\begin{array}{l}0.1 \\
3\end{array}$ & & & \\
\hline \multirow[t]{8}{*}{$\begin{array}{l}\text { Satisfaction with green } \\
\text { spaces and leisure activities }\end{array}$} & \multirow[t]{2}{*}{$\begin{array}{l}\text { Green spaces and spending } \\
\text { leisure time }\end{array}$} & $\begin{array}{l}\text { Smaller } \\
\text { equal } 3\end{array}$ & 138 & $\begin{array}{l}0.8 \\
7\end{array}$ & 0.50 & 0.001 & $\begin{array}{l}2.19 \\
6\end{array}$ \\
\hline & & $\begin{array}{l}\text { Larger } \\
\text { than } 3\end{array}$ & 20 & $\begin{array}{l}0.1 \\
3\end{array}$ & & & \\
\hline & \multirow[t]{2}{*}{$\begin{array}{l}\text { Quality of green spaces and } \\
\text { spending leisure time }\end{array}$} & $\begin{array}{l}\text { Smaller } \\
\text { equal } 3\end{array}$ & 149 & $\begin{array}{l}0.9 \\
4\end{array}$ & 0.50 & 0.001 & $\begin{array}{l}1.86 \\
7\end{array}$ \\
\hline & & $\begin{array}{l}\text { Larger } \\
\text { than } 3\end{array}$ & 9 & $\begin{array}{l}0.0 \\
6\end{array}$ & & & \\
\hline & \multirow[t]{2}{*}{$\begin{array}{l}\text { Abundance of green spaces } \\
\text { and spending leisure time }\end{array}$} & $\begin{array}{l}\text { Smaller } \\
\text { equal } 3\end{array}$ & 155 & $\begin{array}{l}0.9 \\
8\end{array}$ & 0.50 & 0.38 & $\begin{array}{l}2.08 \\
9\end{array}$ \\
\hline & & $\begin{array}{l}\text { Larger } \\
\text { than } 3\end{array}$ & 3 & $\begin{array}{l}0.0 \\
2\end{array}$ & & & \\
\hline & \multirow[t]{2}{*}{$\begin{array}{l}\text { Access to green spaces and } \\
\text { spending leisure time }\end{array}$} & $\begin{array}{l}\text { Smaller } \\
\text { equal } 3\end{array}$ & 142 & $\begin{array}{l}0.9 \\
0\end{array}$ & 0.50 & 0.001 & $\begin{array}{l}2.43 \\
0\end{array}$ \\
\hline & & $\begin{array}{l}\text { Larger } \\
\text { than } 3\end{array}$ & 16 & $\begin{array}{l}0.1 \\
0\end{array}$ & & & \\
\hline \multirow[t]{6}{*}{$\begin{array}{l}\text { The satisfaction of the } \\
\text { cultural-recreational of saheli }\end{array}$} & \multirow[t]{2}{*}{$\begin{array}{l}\text { Sports Coastal recreational } \\
\text { spaces }\end{array}$} & $\begin{array}{l}\text { Smaller } \\
\text { equal } 3\end{array}$ & 73 & $\begin{array}{l}0.4 \\
6\end{array}$ & 0.50 & 0.001 & $\begin{array}{l}3.13 \\
3\end{array}$ \\
\hline & & $\begin{array}{l}\text { Larger } \\
\text { than } 3\end{array}$ & 85 & $\begin{array}{l}0.5 \\
4\end{array}$ & & & \\
\hline & \multirow[t]{2}{*}{ A variety of water sports } & $\begin{array}{l}\text { Smaller } \\
\text { equal } 3\end{array}$ & 149 & $\begin{array}{l}0.9 \\
4\end{array}$ & 0.50 & 0.001 & $\begin{array}{l}1.56 \\
3\end{array}$ \\
\hline & & $\begin{array}{l}\text { Larger } \\
\text { than } 3\end{array}$ & 9 & $\begin{array}{l}0.0 \\
6\end{array}$ & & & \\
\hline & \multirow[t]{2}{*}{ Access to the beach } & $\begin{array}{l}\text { Smaller } \\
\text { equal } 3\end{array}$ & 122 & $\begin{array}{l}0.7 \\
7\end{array}$ & 0.50 & 0.001 & $\begin{array}{l}2.62 \\
0\end{array}$ \\
\hline & & $\begin{array}{l}\text { Larger } \\
\text { than } 3\end{array}$ & 36 & $\begin{array}{l}0.2 \\
30 . \\
5\end{array}$ & & & \\
\hline
\end{tabular}

Average: 2.54

To investigate the satisfaction of social aspect of the quality of residents' life, t-test was used. The questions have been scores together to form a score for each person. The maximum score for each subject is $18 \times 5=$ 90 and the minimum score is $18 \times 1=18$, also the theoretical mean score for this questionnaire is $2 /(90+$ $18)=54$. If the observed values are higher than the theoretical amount 54, it is an expression of approval; and 
if the observed values are less than the theoretical amount 54 is dis approval. As shown clear in table (3), the average mean scores for social aspect is 56.296, which is higher than (54) the average score you can get, Therefore quality of life in the middle level is rather high.

Table 3. The average of participants according to social aspect

\begin{tabular}{llll}
\hline Aspect & Numb & Average & Standard deviation \\
& & & \\
\hline Social & 157 & 56.269 & 0.47
\end{tabular}

\section{Compare the distribution of participants ,male and female:}

\section{Responsiveness Gender:}

According to the graph in total 48.7 percent of respondents were female and 51.3 percent of the respondents were men. Table -4

Table 4. Distribution of respondents in terms of Gender

\begin{tabular}{lll}
\hline Gender & Abundance & Percent \\
\hline Male & 81 & 51.3 \\
Female & 77 & 48.7 \\
Total & 158 & 100.0 \\
\hline
\end{tabular}

Chart 1- distribution of participants in terms of Gender of

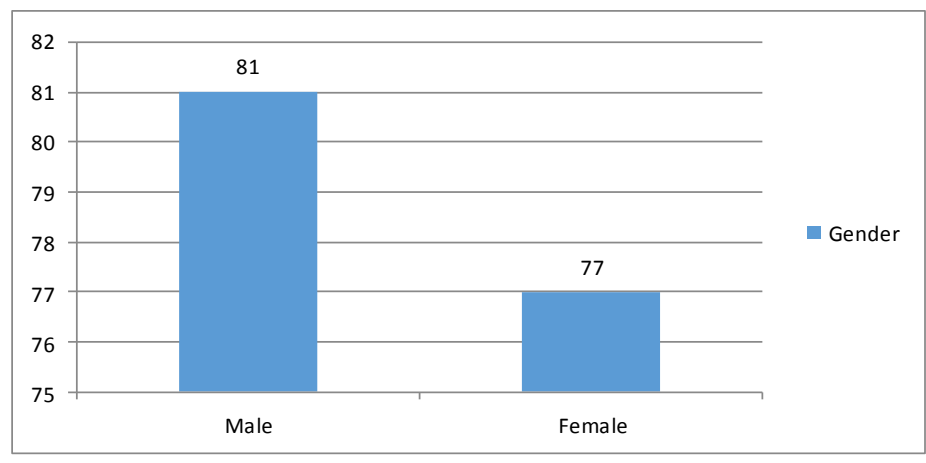

Then we compare the distribution function of men and women response to any of the questions. Because the questionnaire is of Likerth type, and is scored based on rate so Kolmogorov-Smirnov nonparametric test have been used. Amounts related to each sub-criterion are listed in the following tables.

Table 5: Average distribution of female and male respondents

\begin{tabular}{|c|c|c|c|c|c|c|c|c|c|c|c|c|c|c|c|c|c|c|}
\hline & 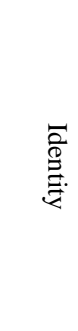 & 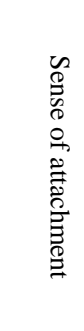 & 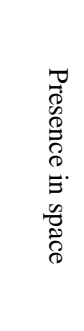 & 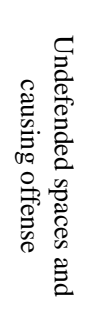 & 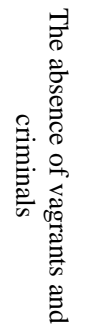 & 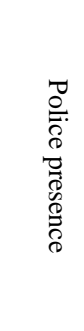 & 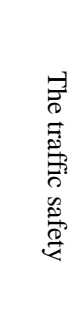 & 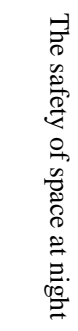 & 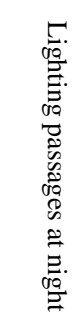 & 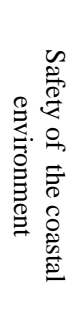 & 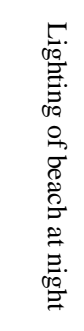 & 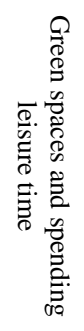 & 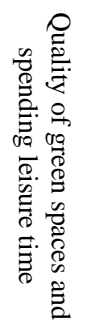 & 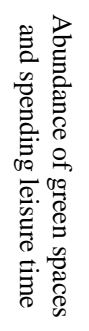 & 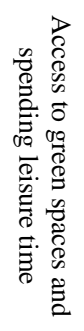 & 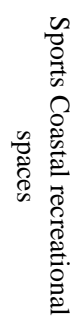 & 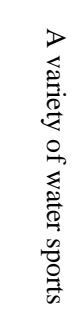 & 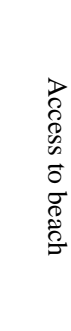 \\
\hline Average men & 2.65 & 2.54 & 2.89 & 3.28 & 3.06 & 2.42 & 2.66 & 3.23 & 2.49 & 2.30 & 2.13 & 2.20 & 2.24 & 1.94 & 2.46 & 2.86 & 1.78 & 2.74 \\
\hline Average women & 2.28 & 2.32 & 2.83 & 3.56 & 3.38 & 2.47 & 2.36 & 3.85 & 2.65 & 2.22 & 2.00 & 2.19 & 1.94 & 1.79 & 2.40 & 3.41 & 1.35 & 2.50 \\
\hline Kolmogorov- & 1.02 & 0.62 & 0.50 & 1.22 & 0.81 & 0.32 & 1.37 & 1.64 & 0.69 & 1.30 & 0.51 & 0.30 & 1.24 & 0.94 & 0.62 & 1.25 & 1.77 & 0.67 \\
\hline \multicolumn{19}{|l|}{ Smirnov } \\
\hline Asymp. Sig. & 0.25 & 0.84 & 0.97 & 0.10 & 0.03 & 1.00 & 0.050 & 0.01 & 0.74 & 0.07 & 0.96 & 1.00 & 0.09 & 0.34 & 0.84 & 0.09 & 0.00 & 0.77 \\
\hline
\end{tabular}


In this study, the two measures of satisfaction of travel security, space security at night and satisfaction of a variety of coastal sports - recreational areas there are significant differences in the distribution of responsiveness between men and women. As shown in Table (5), women and men in answer to the question, "You can do all kinds of water and beach sports to be desired, 1.78 of men were satisfied from doing water and coastal sports, while this level of satisfaction in women is 1.35 . In other words, water and coastal sports facilities for men is more than women. In answer to the question "travel in this area is stress-free ", 2.66 men were satisfied from lack of stress that this rate among women reaches to 2.36. In other words, traveling to men is associated with less stress.

Also in answer to the question, "When the night this area is dangerous for you " 3.85 of women feel a risk at night such that this feel for men is 3.23 , and in other words, women believed that at night there are many risks for them. Also in sub-criterion of security in coastal recreational - sport spaces, the average between men and women is different, but this difference in statistically acceptable level 0.05 and 0.01 is not meaningful but is significant.

\section{Discussion and conclusion:}

The quality of urban life is a complex and multi-dimensional term in relation to situation of people living in a specific geographic scale. Although there are disagreements in the definition of quality of life, cognitive compromise is between specialists that based on it they believe that quality of life has positive aspects and is a multi-dimensional concept and what is certain, is that all the studies on quality of life are done under two headings of objective indicators and subjective indicators. So one of the fundamental characteristics is the multidimensional aspect of quality of life. In this study, we first assess the subjective indicators of quality of life in the social dimension then the difference in the distribution of responsiveness between men and women in the social dimension was evaluated. Therefore, in investigating the first question of research the results obtained indicate that the average of social indicators of quality of life, diversity of water - coastal sports, access to the beach, lack of spaces without offense and causing defense, traffic security , space security at night, space lighting at night and feel the presence of the space is more than average. That is to say the condition of intermediate tissue of Bandar Abbas in these social indicators of quality of life is at an appropriate level. In contrast, the mean of green spaces and spending leisure time, abundance of green spaces and spending leisure time, the quality of green spaces and of spending leisure time, access to green spaces and spending leisure time, a variety of water - coastal sports, police presence, security beach, beach lighting at night, identity and sense of belonging is less than average. But in general, the average of all social indicators of quality of life is higher than average which represents a relatively good state of quality of life of intermediate texture of residents of Bandar Abbas. In general we can say that in subjective dimension the residents in the social dimension have moderate to high rate. Then, considering the second question, the results showed that there is a significant difference in some indicators of the quality of life of women and men in Bandar Abbas. So that the three criteria, traffic security, space security at night and diversity of sports- coastal recreational spaces there are significant differences in the distribution of female and male responses that the difference is more desirable to men than women.

\section{References:}

Azimi, A., (2007), dimensions and indicators of quality of urban life, councils Journal, Issue 55.

Bazargan Harandi, Abbas, (2015), Introduction to qualitative and mixed methods research, common approaches in behavioral science, Fifth Edition, Tehran, Press Didar.

Costanza, R., (2007), "Quality of life: An approach integrating opportunities, human needs, and subjective well-being", Ecological Economics, NO 61(2-3): 56-74.

Cutter,s,(1982) "Residential satisfaction and the suburban home owners", Urban geography,3,pp.315-327.

Das, D., (2008), "Urban Quality of Life: A case study of Guwahati", Social Indicators Research, 88,65-89.

Delfim Saantos, Luise and Isabel Martin (2006) "Monitoring Urban Quality of Life Experience", Social Indicators Research, 80: 411-425.

Gifford, Robert, (1998), perception and recognition, translator; Nasrin Dabashi, Journal of architecture and culture, No second and third. 
Khadem-Al-hoseini, Ahmad, Mansurian, Hussein, Sattari, Muhammad Hussein, (2010), Measurement of Subjective quality of life in urban areas (Case Study: City Nurabad, Lorestan Province), Journal of Geography and Environmental Studies, First Year, Issue 3, Spring 2010.

Kokabee, Afshin. (2007), "Criteria for assessing the quality of urban life in urban centers", Journal of the identity of the city, No. 1, 86-75.

Lovejoy,K.,Handy,S.,\&Mokhtarian,P.(2010).Neighborhood Satisfaction in suburban versus traditional environments:An evaluation of contributing characteristics in eight California neighborhoods.Landscape and Urban Planning . 97(1),37-48.

Mahdizadeh, Javad. (1999), Accounting criteria Industries and utilities, Volume I, Tehran, publisher of the country's municipalities.

Pavot, W., \& Diener, E. (1993). Review of the satisfaction with life scale. Psychological Assessment, 5, 164172.

Qafari, G. Omidi, R., (2006) and quality of life, social development index, published headband.

sarrafi,M.(2003),Concepts,Principles and challenges of urban management, urbanmanagement journal,no.2:68-61.

Sternberg, R. J. (2001). Psychology: In search of the human mind. Fort Worth, TX: Harcourt College Publishers.

Uzell.(2006). "Environment and quality of life", Revue européenne de psychologie appliquée 56, pp 1-4.

VanKamp van Irene, Leidelmeijer Kees, Gooitske Marsman, Hollander Augustinus. (2003), "Urban environmental quality and human well-beingtowards a conceptual framework and demarcationof concepts; a literature study" Landscape and Urban Planning 65 5-18. 